\title{
Nobel somatosensations and pain
}

\author{
Peter W. Reeh ${ }^{1}$ - Michael J. M. Fischer ${ }^{2}$
}

Received: 14 December 2021 / Revised: 17 January 2022 / Accepted: 18 January 2022 / Published online: 14 February 2022

(c) The Author(s) 2022, corrected publication 2022

\begin{abstract}
The Nobel prices 2021 for Physiology and Medicine have been awarded to David Julius and Ardem Patapoutian "for their discoveries of receptors for temperature and touch", TRPV1 and PIEZO1/2. The present review tells the past history of the capsaicin receptor, covers further selected TRP channels, TRPA1 in particular, and deals with mechanosensitivity in general and mechanical hyperalgesia in particular. Other achievements of the laureates and translational aspects of their work are shortly treated.
\end{abstract}

Keywords 50 ion channels $\cdot$ GPCRs $\cdot$ Agonists $\cdot$ Antagonists

Two days after the publication in Nature of the paper from David Julius' lab, that finally led to this year's Nobel Price for Physiology and Medicine, one could see many (white) people with black noses strolling through the rows of posters at the huge US-American Neuroscience Meeting in New Orleans 1997. The publisher had provided a large number of offprints with the black Nature title page depicting a variety of hot chili peppers, but they were quickly out of stock so that a second load of all too freshly printed offprints was supplied. Excited scientists grabbed the paper and curiously rubbed their noses while absorbing the spectacular news on the 'Red-hot receptor' [33].

This article is part of the special issue on Nociception in Pflügers Archiv-European Journal of Physiology

Dedication:

Hermann O. Handwerker, the still active nestor of pain and sensory physiology, had his 80th birthday in 2020; due to the COVID crisis, this event could not adequately be celebrated. We dedicate this article to him who inspired and supported our and others' work for forty and more years.

Peter W. Reeh

peter.reeh@fau.de

Michael J. M. Fischer

michael.jm.fischer@meduniwien.ac.at

1 Institute of Physiology and Pathophysiology, University of Erlangen-Nürnberg, Universitätsstrasse 17, 91052 Erlangen, Germany

2 Center for Physiology and Pharmacology, Medical University of Vienna, Schwarzspanierstrasse 17, 1090 Vienna, Austria

\section{Past history}

The enormous interest in capsaicin and the successful cloning of its receptor channel had exponentially grown since middle of the 1970s. At that time, the groundbreaking works starting in the 1940s on capsaicin of Miclos (Nicholas) Jancso, his wife Aurelia Jancso-Gabor, later his son Gabor Jancso, and his early collaborator, the late Janos Szolcsanyi, had become widely appreciated through publications in English [81, 164]. It was the incomparable-by that time-selectivity of capsaicin's actions that inspired the pain research community: It did not smell, it did not taste, not numb nor damage the oral mucosa but just hurt, inducing the well-known burning pain sensation of Habanero chili. In scientific terms, it did exclusively excite a large and distinct subpopulation of nociceptors anywhere in the mammalian body, but not in avians or amphibians [83]. If concentration and duration of capsaicin application were large enough, the excitation was followed by a sustained insensitivity to heat, but not mechanical, and to chemical (algogenic) stimulation, e.g. by inflammatory mediators like bradykinin or histamine. When capsaicin was systemically administered in rodents or directly applied to nerve endings, peripheral nerve fibres or sensory neurons a lasting, highly selective neurotoxic effect with degeneration and necrosis was achieved that early awakened hopes for a therapeutic utilization [19]. Decades later, Qutenza ${ }^{\mathrm{TM}}$ was approved, a plaster delivering capsaicin to painful neuropathic skin, and is still the only approved direct TRP channel modulator [113]. Promising appears the soon to be expected approval of CNTX-4975, an 
ultrapure formulation of trans-capsaicin to be injected into osteoarthritic joints [157]. A long tradition has the desensitization of the hyperactive ('neurogenic') urinary bladder by capsaicin instillation [42].

\section{Capsaicin receptor TRPV1}

Based on the then accumulated pharmacological evidence, already 1975 the existence of a capsaicin receptor was postulated [165]. With the advent of rat sensory neuron cultivation, intracellular recording indicated that capsaicinchemically a vanilloid-activates an ionotropic receptor, a depolarizing, excitatory ion channel which was soon analyzed in detail by patch-clamp techniques and shown to be an unselective cation conductor [10, 182]. It is not just the 'cherry on the cake' that the capsaicin receptor transient receptor potential vanilloid 1 (TRPV1) was finally cloned from rodent sensory neurons, employing an elegant search technique, but this achievement released an avalanche of other TRP channel discoveries with today (Nov. 2021) more than 19,000 papers in PubMed [188]. These penetrate almost all fields of physiology and medicine, including so diverse disciplines as diabetology, cardiology, or oncology. David Julius and his lab at UC San Francisco contributed at least
48 major publications to this flood of papers. Milestones in the timeline are depicted in Fig. 1.

The cloned and heterologously transfected TRPV1 met all functional expectations: high calcium ion permeability, $\mathrm{Ca}^{2+}$-dependent desensitization and cytotoxicity, specific expression in spinal and trigeminal sensory ganglia, and activation by noxious heat [33]. Only one property required an early second paper to demonstrate the activation of TRPV1 by tissue acidosis as in inflammation, tumours, and ischemic muscle work [169]. This important source of pain can be blocked by an experimental TRPV1 antagonist (BCTC) in a human psychophysical model [69]. Loss of sensory neuronal proton sensing and of inflammatory hyperalgesia was to be predicted from the phenotype of TRPV1 'knockout' mice [31, 44]. However, the reduction of behavioural heat sensitivity was marginal in these knockout animals. Only recently it was shown that in mice three different genes for heat-activated ion channels, TRPV1, TRPA1, and TRPM3, need to be deleted in order to abolish noxious heat avoidance [173]. In clinical trials, it was therefore surprising that some of the developed TRPV1 inhibitors abrogated heat sensing in patients to an extent that burn or scalding injuries were to be feared. However, translational research on sensory neurons and humans (psychophysics) recently confirmed this loss of heat sensing after topical capsaicin-induced desensitization of the skin [144]. Although the TRPV1 antagonists were
Fig. 1 Timeline of milestones. References mentioned only here: $[18,28,35]$

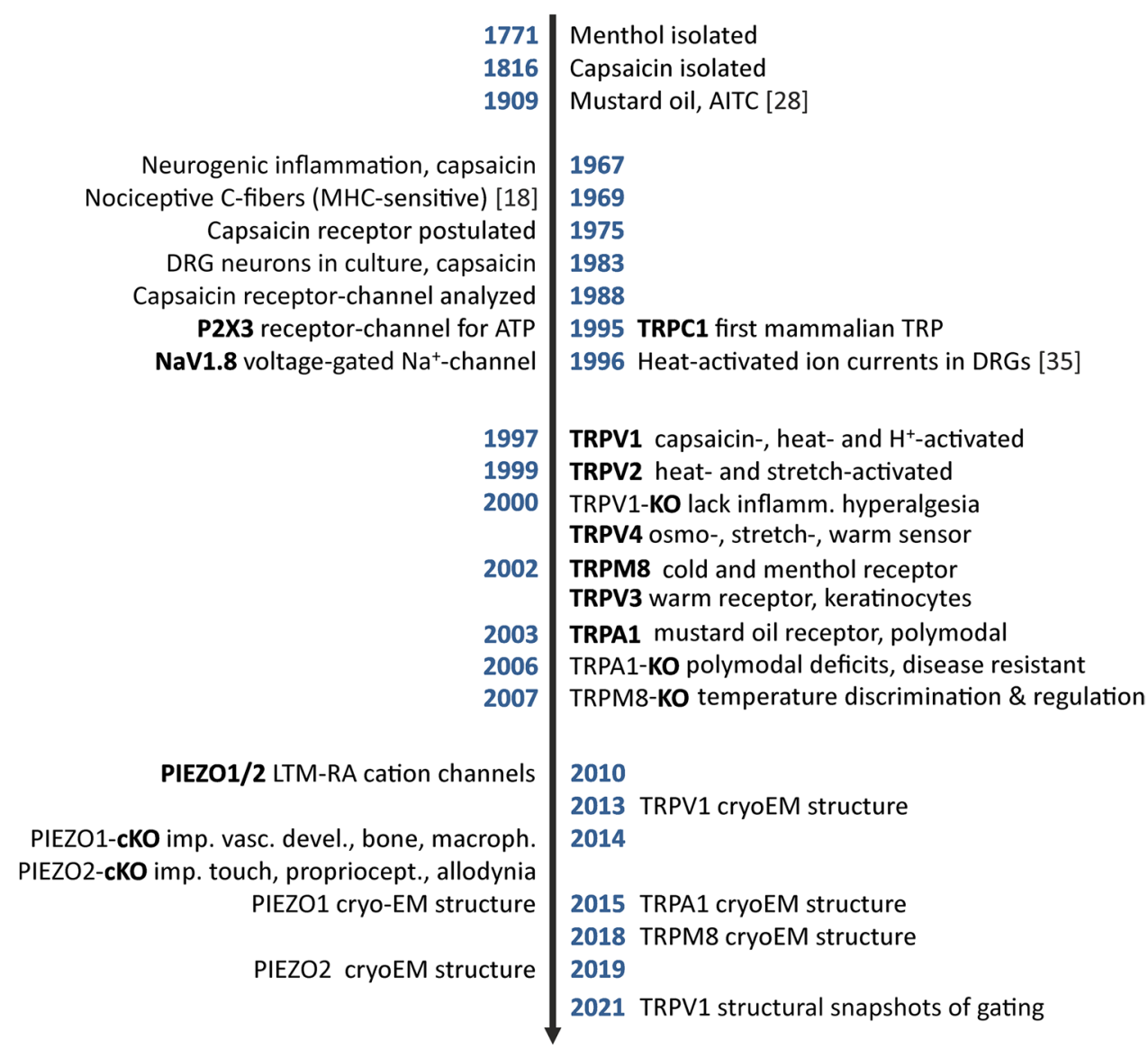


efficacious analgesics, e.g. in osteoarthritic patients, these drugs were not pursued, also because they transiently increased body temperature [91]. Other approaches, leaving the native TRPV1 intact but trying to counteract its sensitisation during inflammation, have unfortunately not been further developed [54, 65, 155]. One new point of attack has recently been proposed: The high calcium conductance of TRPV1 leads to activation of the $\mathrm{Ca}^{2+}$-activated $\mathrm{Cl}^{-}$channel ANO1 co-expressed in nociceptive neurons which amplifies the depolarizing action and action potential discharge; this interaction could be pharmacologically targeted [167].

\section{Integrator and sensitizer TRPV1}

However, scrutinizing the TRPV1 homotetramer with singleparticle cryo-electron microscopy revealed potential allosteric activation mechanisms and ligand binding sites that may in the future allow to develop targeted small molecules to interfere with one but not the other function of the polymodal receptor channel [27, 97]. The cryo-electron microscopy and related studies also helped to better understand the paramount capacity of TRPV1 to integrate a multiplicity of endogenous ('endovanilloids') and exogenous stimuli by enabling synergistic or sensitizing actions of the different signals. Much of this capacity is based on the action of phospholipase C (PLC)a common activator of many TRP channels - to remove the double-edged effectors phosphatidylinositol-4,5-bisphosphate $\left(\mathrm{PIP}_{2}\right)$ and phosphatidylinositol 4-phosphate (PI4P) from the membrane domain hosting TRPV1 [26, 64]. Many G protein-coupled receptors such as the B2 receptor for bradykinin activate PLC and also disinhibit TRPV1. In addition, diacylglycerol (DAG), resulting from PIP2 cleavage by PLC, activates protein kinase $\mathrm{C}$ which phosphorylates and further promotes TRPV1 activation. This cascade of events can, for example, lower the heat threshold of rat skin nociceptors as far as below body temperature, thus likely producing inflammatory pain [96]. Also protein kinase A, activated through prostaglandin receptors, can sensitize TRPV1 which may be the reason why the COX inhibitor ibuprofen, orally or topically administered, strongly reduced the pain from experimental tissue acidosis in the skin and muscle in the above-mentioned human model [156]. Later, cryo-EM investigations using lipid nanodiscs generated snapshots of TRPV1 in interim states, providing a glimpse at how gating works [186].

\section{An earlier TRP and other 'pain-related' channels}

TRPV1 was not the very first 'pain-related' ion channel to be cloned, though particularly seminal. John Wood and his lab had previously discovered the $\mathrm{P} 2 \mathrm{X} 3$ receptor channel for extracellular ATP and diadenosine polyphosphates ('alarmones') which are cellular stress signals [36]. In 1996, they had cloned the TTX-resistant voltage-gated sodium channel $\mathrm{NaV} 1.8$ which turned out indispensable in nociceptors for action potential generation and encoding of discharge rate at noxious cold and hot temperatures [3, 170, 189]. TRPV1 was also not the very first TRP channel to be cloned, as Craig Montell's lab (Johns Hopkins, Baltimore, at the time) had previously discovered TRPC1, the human homolog of the drosophila mutant $\mathrm{Ca}^{2+}$ channel involved in phototransduction that had led to the misnomer transient receptor channel (TRP) [178]. In fact, TRPV1 behaves only 'transient', i.e. desensitizing, inactivating during ongoing stimulation, if $\mathrm{Ca}^{2+}$ entry through the channel is not prevented by removing and adequately buffering extracellular calcium [33]. A recent review article provides an overview of the TRP channel superfamily and its 28 mammalian members [171].

\section{TRPV2}

The big wave of TRP channel discoveries gained momentum 1999 with the cloning by David Julius' lab of the rodent TRPV2, capsaicin insensitive but still named ' $\mathrm{V}$ ' for its similarity to TRPV1. TRPV2 first appeared as a heat transducer for temperatures $>50^{\circ} \mathrm{C}$, but global knockouts showed no thermo- or mechanosensory deficits even in inflamed skin [32, 126]. However, sensory neuron-specific conditional TRPV2 knockout mice were hyposensitive to noxious pressure and a distinct subpopulation of their sensory neurons lacked stretch-activated $\mathrm{Ca}^{2+}$ influx [85]. Stretch activation and high expression of TRPV2 in cardiomyoctes prompted clinical studies in dilated cardiomyopathy [80]. TRPV2 also plays a role in innate immunity by its expression in macrophages which require the channel for efficient phagocytosis. Like many TRP channels, TRPV2 is redox sensitive, even the human homolog, originally insensitive to heat, gains heat sensitivity with thresholds below body temperature when oxidized, and, vice versa, macrophages reduce their phagocytic activity when exposed to reducing agents [57].

\section{TRPV4}

TRPV4 was cloned in 2000 as an osmoreceptor for hypotonicity and putative stretch receptor but soon shown also to serve as a transducer for warm ambient temperatures [62, 98]. TRPV4 was the first TRP channel mutations of which were associated with various genetic diseases in humans ranging from asthma over skeletal dysplasias to neuropathy; global knockout mice show deficits in various visceral pain models [179]. The complex phenomenologies are due to a 
very widespread expression of TRPV4 in many cell types and organs, i.e. in epithelial cells, particularly keratinocytes [91]. A stunning cascade of events leading to cholestatic itch in liver diseases has recently been established: Enhanced blood and skin levels of lysophosphatidylcholine (LPC) activate TRPV4 in keratinocytes which in response release the particular microRNA-146a known to act as an inflammatory mediator in the innate immune system. This acts probably through toll-like receptor 7 (TLR7) which finally activates TRPV1 in nociceptors, some of which also act as pruriceptors inducing itch [37].

\section{Price worthy TRPs, TRPV3 and TRPM8}

In 2002, the second Nobel laureate Ardem Patapoutian entered the stage of TRP channel discoveries. TRPV3 was cloned in his lab at the Genomics Institute of the Novartis Research Foundation in La Jolla/San Diego, adjacent to the Scripps Research Institute where he moved soon after [131]. TRPV3, activated by warm temperatures $\left(>32^{\circ} \mathrm{C}\right)$, was abundantly expressed in skin keratinocytes, not in rodent but in human sensory (DRG) neurons, and accordingly, from knockout mice no alterations in thermal preference and noxious heat withdrawal were reported [79]. TRPV3 found great attention in dermatology, a human gain-of-function mutation is in part responsible for the hyperkeratotic and mutilating Olmsted syndrome; TRPV3 plays roles in the control of hair growth and lipid secretion, in atopic dermatitis and pruritus [91, 107]. However, by optogenetic inhibition of keratinocytes in mice, it was recently shown that stimulated ATP release from these cells contributes to behavioural heat, cold, and mechanosensitivity through neuronal $\mathrm{P} 2 \mathrm{X} 4$ purinoceptor channels [109, 147], and TRPV3 expression is essential for the heat-induced ATP release that is able to activate nearby DRG neurons in co-culture with keratinocytes [103].

Also 2002, the cold transducer and menthol receptor TRPM8 was cloned in Patapoutian's and, independently, in Julius' lab [106, 131]. TRPM8 is particular among the TRPs, as it is alone largely responsible for the delicate sense of cooling, being expressed in the 'cold' fibres, unmyelinated $\mathrm{C}$-fibres in rodents and thinly myelinated in humans. Due to the widely overlapping stimulus-response curves of 'warm' and cold fibres around body temperature, TRPM8 indirectly also contributes to the equally delicate sense of warming. Ongoing activity in cold fibres and their input to the CNS appear to inhibit the throughput of warm fibre activity; temperature increase immediately silences the cold fibres and, thus, enables the perception of warming [125]. Accordingly, TRPM8 knockouts cannot discriminate between warm and cool stimuli; in addition, they do not exhibit inflammatory or neuropathic cold allodynia, a painful sequelae of cancer chemotherapies [12]. These knockout mice also tend to develop obesity due to day-time hyperphagia; and ageing wildtypes, showing reduced TRPM8 expression and function, cannot properly prevent heat loss by vasoconstriction in cool environment [141, 168]. Vice versa, TRPM8 agonist treatment in wildtypes leads to enhanced energy expenditure and loss of body weight [39]. The inhibitory action of TRPM8 expressing cold fibres seems to extend to nociception: Hyperalgesia in neuropathy and inflammatory models was antagonized by the TRPM8 agonists menthol or icilin at the affected skin or upon intrathecal administration; these analgesic effects were lost after specific knockdown of TRPM8 by intrathecal antisense oligonucleotides [134]. Moreover, a human population identified by single nucleotide polymorphism in or near the TRPM8 gene has been found to carry a reduced risk of migraine headaches. Carriers also show a reduced expression of TRPM8 in DRGs (post mortem) and, in vivo, a correlating reduction of cold and cold pain sensitivity [59]. These findings justify the clinical studies with menthol and various TRPM8 antagonists against pain and itch [91]. A particular role of TRPM8expressing nerve fibres in the cornea has been identified: When the tear film on the eye evaporates, the temperature drops and the osmolality increases; both effects are adequate stimuli to TRPM8 and lead to reflex blinking and lacrimation $[127,136]$. The structure of TRPM8 has been discovered by cryo-EM [184].

\section{TRPA1, almost universal chemosensor and polymodal receptor}

Although an ankyrin-rich TRP-like protein was first identified in 1999 in human fibroblasts, its huge potential as ANKTM1, soon renamed TRPA1, came to appearance in 2003 with its cloning in Patapoutian's lab. First described as a noxious cold transducer, its role as a chemosensor for many pungent plant compounds such as the volatile mustard oil ingredient allyl-isothiocyanate (AITC, e.g. in horseradish) was soon recognized and its function as an effector ion channel for bradykinin and products of phospholipase activation such as arachidonic acid and diacylglycerol $[11,158]$. David Julius' lab soon joined in, extending the library of TRPA1 agonists to other isothiocyanates and, surprisingly, to delta(9)-tetrahydrocannabinol (THC) that was already in fashion as a would-be analgesic and now turned out to be a potentially painful irritant. In addition, they confirmed the TRPA1 activation by $\mathrm{G}$ protein-mediated phospholipase $\mathrm{C}$ (PLC) activation and provided first evidence for TRPA1 gating by intracellular calcium ions [82]. Meanwhile, the binding pocket in TRPA1 for intracellular $\mathrm{Ca}^{2+}$ ions, accounting for activation, desensitization, and metabotropic modulation, has been identified by cryo-EM analysis and the mechanisms of cysteine-dependent activation by intracellular 
electrophilic compounds as AITC have further been elucidated [187]. The latter involves a most unusual covalent, but not irreversible, ligand binding principle, which can lead to the formation of activating disulphide bridges between adjacent cysteine thiols. This applies, for example, to methylglyoxal, a cytotoxic side product of glycolysis, accumulating in diabetic or uremic patients and contributing to their potential development of painful neuropathy [48]. Methylglyoxal belongs to the highly reactive endogenous carbonyl species (RCS) that are TRPA1 agonists as well as the reactive oxygen and nitrogen species (ROS, RNS) such as $\mathrm{H}_{2} \mathrm{O}_{2}$ and peroxynitrite $[6,8]$. However, $\mathrm{H}_{2} \mathrm{O}_{2}$ is used in molar concentration to clean and disinfect wounds which does not hurt, in contrast to the TRPV1 agonist ethanol. Reason for the discrepancy is that many of the reactive species, in particular $\mathrm{H}_{2} \mathrm{O}_{2}$, are relatively impermeable and therefore much more potent at oxidizing proteins like TRPA1 if generated, or experimentally applied, intracellularly. An example is again methylglyoxal which is overproduced in the insulin-independent neurons under the substrate pressure of hyperglycaemic episodes in diabetes, potentially evoking pain [7]. Other examples are $\mathrm{Fe}^{2+}$ ions as in heme which potentiate $\mathrm{H}_{2} \mathrm{O}_{2}$ activation of TRPA1 by catalytic formation of hydroxyl radical $(\mathrm{OH})$, or the heme precursor protoporphyrin IX, a chromophore present in all cell types, which generates singlet oxygen $\left({ }^{1} \mathrm{O}_{2}\right)$ activating TRPA 1 under the influence of violet visible light ( $406 \mathrm{~nm}$ ). This causes pain when unpigmented human skin is irradiated, which serves as a model for the painful photosensitivity of porphyria patients [9, 72]. Near ultraviolet light (UVA) could also act through creating oxidative stress, but in human melanocytes it is a UVA-induced, retinal- and opsin-dependent activation of PLC that activates TRPA1, channelling $\mathrm{Ca}^{2+}$ ions which stimulate the cellular melanin synthesis [16]. This is a striking example for the widespread extraneuronal TRPA1 expression, particularly in epithelial cells, which makes the development of TRPA1 blockers for clinical use so difficult and lengthy, although preclinical results are most promising. On the other hand, epigenetic regulation of expression of TRP channels in diseases and overexpression in certain tumours may open new therapeutic options [70, 91].

TRPA1 is the most polymodal receptor channel of all TRPs, activated or inhibited by hundreds of natural and synthetic chemicals including common drugs such as dipyrone (metamizol) and acetaminophen (paracetamol), the latter accounting for analgesic and antipyretic effects [61, 77, 119, 149], and somehow contributes to noxious heat and cold transduction [74, 110, 154]. Particular chemical cases are cigarette smoke and its nicotine-free gaseous phase, tissue acidosis activating only the human TRPA1 but not rodent and non-human primate homologs, and nitroxyl anion $\left(\mathrm{H}^{+} \mathrm{NO}^{-}\right)$which results from the chemically unusual interaction of the two gasotransmitters $\mathrm{H}_{2} \mathrm{~S}$ and NO. [47, 87, 142].
TRPA1 channelopathy and other diseases

A peculiar human TRP channelopathy discovered in members of a Colombian family is a gain-of-function mutation in the TRPA1 gene that leads to severe upper body musculoskeletal pain attacks when fatigue, exhaustion, hunger coincide with a chilly environment [92]. This familial episodic pain syndrome (FEPS1) and its very particular characteristics may result from an inhomogeneous composition of the TRPA 1 tetramer, consisting of wildtype and mutant monomers in various combinations [117]. Among the preclinical disease models, TRPA1 is involved in almost all painful or pruritic disorders, prominently in respiratory (cough), pancreatic, and inflammatory bowel disease (IBD) models [70, 91]. In three models of chemically induced colitis (TNBS, DSS, oxazolone), TRPA1 gene deletion or pharmacological block prevented or cured the disease. In addition, the TRPA1-mediated (via $\mathrm{Ca}^{2+}$ influx) neuropeptide release, of substance $\mathrm{P}(\mathrm{SP})$ in particular, was identified as the decisive disease promoter; disruption of SP signalling also had preventive or curative effects [50-52]. These findings, including the detrimental role of SP, were soon corroborated in pancreatitis models [34]. Nonetheless, the gastrointestinal research field is still controversial with respect to TRP involvement, also because none of the disease models is fully accepted to reproduce the human diseases [43]. Part of the controversy resulted from the use of capsazepine, a classical capsaicin antagonist developed long before TRPV1 was cloned; the much-used drug tool was reported to exert curative effects in models of colitis and pancreatitis $[58,180]$. However, it then turned out that these beneficial effects were the same in global TRPV1 knockouts, and that capsazepine actually acted as a weak TRPA1 agonist with strong desensitizing aftereffects [90]. Systemically administered (in drinking water) capsazepine even achieved a body-wide desensitization against noxious heat stimuli and chemical irritants in wildtype mice but not TRPA1 knockouts-much like systemic capsaicin (or resiniferatoxin) would do, reflecting the co-expression of TRPA 1 and TRPV 1 in sensory neurons and their cross-desensitizing effects [89].

\section{TRPA1 and other mechanosensitivities}

The direct and indirect mechanosensitivity of TRPA1 completes the picture of TRPA1 polymodality. Its mechanosensitivity was discovered in David Corey's lab where global knockouts had been generated that showed deficits in sensing ice cold, chemical, and punctate mechanical stimuli [94]. Ardem Patapoutian's and a collaborating lab 
soon joined in demonstrating mechanical activation of TRPA1 first in C. elegans and then in mice where it contributes to inflammatory hyperalgesia [88, 132]. Recently, the inherent responsiveness to graded (negative) pressure of the purified hTRPA1 protein reconstituted in artificial lipid bilayer has been established by single-channel patch-clamp recordings [111]. A hint for the mechanism of activation comes from lipopolysaccharides, toxic decay products of Gram-negative bacteria that activate TRPA1 without being able to bind to the receptor. Instead they integrate into the outer leaflet of the neuronal membrane, distorting it and exerting 'force-from-lipid' on the transducer channel [108]. This concept had been introduced in 2004 and explained by 'hydrophobic mismatch' between lipophilic amino acid helices of the transmembrane components of stretch-activated ion channels and the surrounding lipid bilayer [159]. The authors employed a tarantula toxin (GsMTx4) that inhibited mechanosensitive TRPC1, TRPC6, and other stretch-activated ion channels but later was shown to also activate TRPA1 potently [71]. A stunning example for the versatile application of mechanosensitivity in evolution is Drosophila vision where stretch activation of TRP and TRPL ion channels by force-fromlipid is the final step in the 'photomechanical' transduction cascade that leads to measurable contraction of the omatidium [68].

Mechanical hyperalgesia is the main reason for chronic pain in daily life, e.g. in osteoarthritis. One reason why the mechanisms of painfully exaggerated mechanosensitivity are not fully unravelled is that so many functional proteins show mechanosensitive properties, one way or the other. Not only ion channels and $\mathrm{G}$ protein-coupled receptors but even the ubiquitous phospholipases are mechanosensitive due to their 'interfacial activation', enhancing the catalytic activity 1000-fold upon contact of the enzymes with the inner leaflet of the plasmalemma which is induced by increased membrane tension, heating, submicromolar $\mathrm{Ca}^{2+}$ concentrations, or ERK/MAPkinase signalling [115]. This mechanism may be involved in the dramatic increase of prostaglandin E2 release from the mouse colon upon distension by intraluminal pressure. The same stimulation also leads to a graded release of vasoactive neuropeptides (CGRP and SP, 'neurogenic inflammation') from colonic primary afferents and, in vivo and in parallel, to a measurable (iEMG) muscular defence reaction in the abdominal wall [114, 145]. Both 'visceromotor' response and CGRP release upon colonic distension depend largely and to about equal degrees on TRPV4 and TRPA1 expression and can pharmacologically be diminished by selective inhibitors. However, not every neuronal membrane equipped with TRPA1 is mechanosensitive. Nociceptive nerve fibres in peripheral nerves do express TRPA1 as well as TRPV1 in their axolemma and respond to AITC as well as to capsaicin and heat, just like their nerve endings in the skin, but they are not sensitive to pressure, not even to forces much higher than required to excite their polymodal terminals $[17,75,177]$. This selective suppression of one but not the other modality could possibly be due to equally mechanosensitive antagonists such as the twopore domain $\mathrm{K}^{+}$channels (K2P) TRAAK and TREK1 that could counteract the depolarization by TRPA1 by hyperpolarizing currents. Their activation by force-from-lipid is well established [23, 24]. Both K2P channels also play a role in the fine adjustment of noxious heat and cold sensitivity, counteracting TRPV1 and TRPM8 [120].

Unravelling mechanosensitivity has recently been further complicated by the optogenetic demonstration that Schwann cell processes, joining sensory nerve terminals into the epidermis, transduce and transmit not only heat and cold but also mechanical stimuli, evoking pain-related behaviours in mice [1]. The transducers and transmitter of the Schwann cells have not yet been identified, but the findings remind of the above-mentioned TRPV 3 and TRPA 1 expression in keratinocytes that confers the same sensory capacities on cells that are also in close contact with nociceptive nerve endings in the skin [147]; as a possible transmitter, ATP had previously been proposed [103]. In addition, PIEZO1 and PIEZO2 have recently been found in keratinocytes and in Schwann cells, respectively [76, 153].

\section{Nobel-prized PIEZOs}

In view of the confusing multiplicity of cell types showing mechanosensitivity and the large variety of possible mechanisms, the discovery in Ardem Patapoutian's lab of the PIEZO channels feels like the revelation of a great unifying concept [41]. Indeed, they account for a whole range of lowthreshold mechanosensitivities in various cell types and sensory nerve terminals. Like expression cloning for TRPV1, also identification of the PIEZOs required persistence for a brute force approach on mouse Neuro2A neuroblastoma cells which showed constitutive mechanosensitivity [123]. Candidate genes with transmembrane domains were addressed one-by-one by means of RNA silencing until the mechanoreceptor, encoded by the Fam38A gene, was found. The last one of 72 candidates brought this success. The receptor was named PIEZO1, derived from $\pi \imath \varepsilon \dot{\zeta} \zeta \omega$ the Greek word for exerting pressure. In hindsight, there are also Greek words for touch or stretch, but the existence of technical piezoelectric sensors, which convert movement into voltage, was suggestive. PIEZO1 is sufficient to endow HEK293t cells with a mechanically induced unselective cation current in response to perturbation of the lipid bilayer [45]. Its molecular size as well as 38 transmembrane domains by far exceeded known ion channel families at the time. Although PIEZO1 expression is reported from sensory neurons, [143], the important 
role is played by its only known sibling, PIEZO2, which was identified by sequence homology. The latter is not only present in DRG neurons but also expressed in the cutaneous Merkel cells that form a functional complex ('touch dome') with the terminals of a fast conducting $\mathrm{A} \beta$-fibre; together they constitute an exquisitely sensitive tactile receptor [181]. Mice with a conditional deletion in DRGs of the gene for PIEZO2 showed severe deficits in proprioception and cutaneous mechanosensitivity [139], much like patients with a lack-of-function mutation who exhibit ataxia and dysmetria in addition to a lack of interoception and discriminative touch perception [38].

\section{PIEZOs beyond somatosensation}

With the establishment of PIEZO2 in mechanosensation, Ardem Patapoutian focussed on other body sites. This sparked a remarkable set of so far 30 publications alone from his laboratory, and occurrences in far more functions than expected. PIEZO2 is found in the vagal stretch receptors of the tracheobronchial wall and is important for regular breathing in neonatal life and later for the Hering-Breuer lung inflation reflex that ends inspiration and initiates expiration and bronchial relaxation [121]. Enterochromaffin cells in the gastrointestinal tract are mechanosensitive through PIEZO2 and this regulates serotonin release controlling secretion and motility [5]. In the bladder, PIEZO2 is found in urothelial cells as well as in the innervating afferent neurons subserving urinary function [105]. As previously mentioned for the skin, the dual appearance in neuronal and nonneuronal cells required targeted deletions to conclude on the relative importance of the receptor in a particular cell type.

PIEZO1 can keep up with the multiplicity of diverse functions of PIEZO2. PIEZO1 in endothelial cells is essential for vascular development and remodelling due to its sensitivity for blood flow-induced shear stress [138]. Red blood cells require PIEZO1 to cope with the mechanical stress when passing narrow capillaries [25]; rare mutations in the gene lead to different syndromes causing haemolytic anaemia in patients [4]. A PIEZO1 gain-of-function variant with about $30 \%$ prevalence in Africa was shown to reduce red blood cells size and to increase resistance against Plasmodium falciparum infection [101]; whether the same variant is of importance for glaucoma is less clear [13]. This variant also shows a role of PIEZO1 in upregulating phagocytic activity of macrophages which leads to increased erythrocyte turnover and elevated plasma iron levels [102]. PIEZO1 in osteoblasts plays a role in bone homeostasis and remodelling; the conditional deletion of the channel leads to reduced bone mass and fractures [174]. This seems to be mediated by an effect of PIEZO1 on developmental fate in the osteoblastic lineage [160].
A major step forward was the discovery of a chemical agonist for PIEZO1, the first called Yoda1 [162], followed by the chemically different Jedi1/Jedi2 [176], demonstrating druggability, but still with limited potency. These substances do not activate PIEZO2, for which no agonist has been discovered. The engineering of chimeras between PIEZO1 and PIEZO2 helped to identify the PIEZO1 binding sites for these agonists [95]. An important leap was solving the cryo-EM structures of PIEZO1 [60, 63, 148], and PIEZO2 [175]. The receptor channels are trimers ( $>1$ MegaDalton) with large propeller-like blades around an extracellular 'nano-dome', which generate a large in-plane membrane area expansion. Deformation of the latter opens the pore, but more work is still required to elucidate the molecular mechanics [166].

\section{PIEZO2 and pain}

The Nobel committee's press release hardly mentioned the word pain in conjunction with PIEZO2, although mechanically induced pain and hyperalgesia under the physical loads of daily life are a scourge of humanity with a large unmet medical need. However, PIEZO2 does seem to be involved in pain, although mainly in the particular pathophysiology of tactile allodynia, painful sensations evoked by touching or brushing affected skin, which are a hallmark of neuropathic syndromes. This phenomenon is attributed to 'central sensitization': Enhanced transmission of non-nociceptive input to spinal dorsal horn neurons in the nociceptive pathway; transient noxious stimulation can temporarily induce this condition and heating capsaicin-treated skin is a human model. Applying this model to the patients with a loss-offunction mutation in the gene for PIEZO2 failed to cause tactile allodynia, consistent with their inability to detect light touch and vibration but in contrast to their largely retained perception of innocuous and noxious pressure [29, 163]. These results are in agreement with findings from conditional PIEZO2 knockout mice that showed major deficits in responsiveness to various weak mechanical stimuli but only minor reduction of responses to pin prick and pinch. Singlefibre recordings from $\mathrm{C}$ - and $\mathrm{A} \delta$-nociceptors in the ex vivo saphenous nerve-skin preparation showed only reductions of the short dynamic phase of discharge evoked by noxious punctate force stimulation, the subsequent static discharge phase was the same in knockouts and wildtypes [116]. In the rat skin, only $\mathrm{C}$ - and $\mathrm{A} \delta$-nociceptors but not low-threshold $A \beta$-mechanoreceptors were able to encode different noxious pressures over two minutes of constant stimulation, and only the high-threshold A $\delta$-fibres (HTM-A $\delta$ ) got markedly sensitized by such traumatic stimuli, which corresponds to mechanical hyperalgesia after pinching human skin folds [67, 140]. Similar myelinated high-threshold 
mechanoreceptors able to discriminate intensities of noxious mechanical stimuli have recently been found by human microneurography, but the patients with PIEZO2 loss-offunction were able to discriminate the stimuli that excited those nerve fibres [118].

Apart from low-threshold mechanoreceptive (LTM) $\mathrm{A} \beta$-fibres that all express PIEZO2, this expression in LTM $\mathrm{C}$-fibres has not safely been established [66]. These slowly adapting fibres have been shown to contribute to tactile allodynia in mouse models of inflammation, nerve injury, and trauma [56, 152]. Paradoxically, the same LTM C-fibres seem to mediate pleasant, rewarding touch in humans, whereas they also contribute to signalling pain in the rodent formalin test that is largely mediated by TRPA1 activation $[99,172]$.

The other extreme in the skin is represented by the apparently mechanoinsensitive $\mathrm{C}$-fibres $\left(\mathrm{CM}_{\mathrm{i}}\right.$ or C-MIA, 'sleeping' or 'silent' nociceptors) that respond vigorously to capsaicin and histamine and can be sensitized to mechanical stimulation by inflammatory mediators including nerve growth factor (NGF). $\mathrm{CM}_{\mathrm{i}}$-fibres have been demonstrated in rat and non-human primate skin as well as by human microneurography [93, 122, 151, 183]. In mouse skin, $\mathrm{CM}_{\mathrm{i}}$ have not safely been identified [73]. Recently, a novel biomarker for $\mathrm{CM}_{\mathrm{i}}$ in mouse sensory neurons has been discovered, the nicotinic acetylcholine receptor subunit alpha-3 encoded by the CHRNA3 gene, and it was shown that the labelled DRG neurons project to visceral organs and other deep tissues but not to the skin. These initially mechanoinsensitive neurons (in primary culture) express PIEZO2 and become responsive to mechanical stimulation after prolonged treatment with an inflammatory mediator combination or with NGF [133]. This corroborates earlier work from Patapoutian's lab showing that bradykinin, by activation of protein kinase $\mathrm{A}$ or $\mathrm{C}$, potentiates mechanically evoked inward currents through PIEZO2 [46]. In addition, a neuronal upregulation of PIEZO2 immunoreactivity has recently been described that follows upon cutaneous inflammation, osteoarthritis, and in neuropathic pain models [153]. This may indicate an epigenetic upregulation of PIEZO2 expression that may not only 'awaken sleeping' nociceptors in viscera, but also enhance the mechanosensitivity of the 'ordinary' polymodals in the skin. Acute exposure of those mechano-heat-sensitive C-fibres to a combination of inflammatory mediators is not sufficient to sensitize them to mechanical stimulation, although it most effectively enhances heat responsiveness [150]. This suggests that a transcriptional upregulation is required to achieve sustained mechanical hypersensitivity as induced, for instance by axonal transport of NGF and activation of ERK1/2 regulating nuclear gene expression [133]. Microinjection of NGF in human skin induces delayed mechanical hyperalgesia lasting for up to seven weeks but also increases cold and heat sensitivity for up to three weeks, suggesting upregulation of several sensory transducers [146]. Consequently, several pharmaceutical companies have developed monoclonal antibodies against NGF and performed clinical trials on osteoarthritic pain, but none has yet been approved by FDA and EMA, perhaps because the drugs were 'too good', seducing patients to overload their worn-out joints with sportive activities which too often led to joint replacement surgeries [137].

Finally, a large discrepancy needs to be discussed that occurs between the DRG patch-clamp and the single-fibre or microneurographic recordings: The mechanically evoked depolarizing currents are all more or less rapidly adapting within a range of some hundreds of milliseconds. However, the discharge activity of 'real' nociceptors, i.e. cutaneous nerve endings, lasts as long as the noxious pressure is maintained following an initial dynamic response $[67,78]$. This indicates a heterogeneity of mechanically evoked currents, which leaves room for the previously mentioned mechanosensitivities of other mechanisms of stretch activation. The discrepancy goes even further, considering that a constant noxious pinch of human skin causes increasing pain, while the nociceptors clearly show adaptation, though with hundreds of seconds time constant [2, 55, 67]. This contradiction may be resolved by recruitment of initially unaffected nociceptors through diffusing mediators (neuropeptides, arachidonic acid derivatives) released from the bruised skin. Indeed, HTM A $\delta$-fibres show delayed and crescendo-like discharge activity when skin just outside their receptive field is sustainably pinched [140]. This sensitizing mechanism may involve closing the $\mathrm{K} 2 \mathrm{P}$ channels and/or activating the TRP channels which are chemosensors in the first place.

\section{Other discoveries of the laureates}

The Nobel Prize has been awarded 'for their discoveries of receptors for temperature and touch'. However, the laureates also have other achievements that are less well known. As a punctual and incomplete selection, David Julius has cloned the serotonin receptor 5-HT1c [84], the only ionotropic 5-HT3 serotonin receptor [104] and an ATP receptor [100]. He also addressed $\mathrm{G} \alpha$ protein coupling [40] before he turned his expression cloning expertise towards the discovery of TRP channels [30]. Several unusual channel functions have been elucidated by his affinity to toxins, not only modulating TRP channels [22] but also a coral snake toxin acting on acid-sensing ion channels [21], a tarantula toxin acting on $\mathrm{NaV1.1}$ [124], a pit viper toxin causing ATP release [185], or a snail toxin inhibiting 5-HT3 receptors [53]. As a side note, papers considering electroception [14, 15], itch [49], but also the heterogeneity of mechanosensitive sensory neurons should be mentioned [20]. The latter topic leads to Ardem Patapoutian, who started with developmental 
biology. The first first-author papers consider muscle development in mice $[129,130]$ before turning to the development of sensory neurons. Here, wnt-based development through neurotrophin signalling [128] and TrkA and TrkC influence on neuronal fate should be mentioned [112]. The papers considering TRP channels dominate the publication list in the period 2002-2011 which switches to PIEZO channels thereafter. Exceptions are the contributions to the physiology of volume-regulated anion channels [86, 135, 161], although an association with mechanical activation could be argued.

\section{Translational relevance in medicine}

For the few who suffer from a rare disease and undergo human genetic diagnostics, understanding the functions of the described ion channels allows to judge whether a genetic alteration fits to the observed phenotype. Several single nucleotide polymorphisms or other mutations with phenotypic consequence are already known. The time of individual gene editing will come; therefore, loss- or gain-of-function mutations with a severe phenotype in well-understood ion channels could, one day, prompt gene-therapeutic correction.

For the many other patients, new pharmacological options would be relevant. So far, these have not materialized, and this could perhaps never happen due to the widespread bodily functions of these targets. Despite extensive efforts to target the TRP channels, no TRP channel inhibitor is on the market; considering TRPV1, many drug development projects have been scrapped-perhaps overprotectively—due to adverse effects. Also, more recently developed compounds not increasing body temperature seem to lack efficacy, although this cannot be well judged as little is published about 'failed' trials. The PIEZOs are involved in so many physiological functions that it remains open whether there will be indications where intended effects would outweigh off-target effects. In case there were tissue-specific cofactors of PIEZO channels, these might also allow to target their function only in a particular tissue. Epidermal application of antagonists for patients with mechanical hypersensitivity could avoid systemic side effects.

Even at this time, when the milestones of scientific discovery contributed by the Nobel laureates have not manifested in therapeutic options for the population at large, the fundamental importance of knowing and understanding a physiological mechanism on which models of disease are resting can hardly be overstated.

Acknowledgements We take the opportunity to thank the laureates for their open interaction with the research community, in our personal case, e.g. in the form of advice and plasmids used on a regular basis so that we could contribute to build on their achievements.
Funding Open Access funding enabled and organized by Projekt DEAL.

\section{Declarations}

Conflict of interest The authors declare no competing interests.

Open Access This article is licensed under a Creative Commons Attribution 4.0 International License, which permits use, sharing, adaptation, distribution and reproduction in any medium or format, as long as you give appropriate credit to the original author(s) and the source, provide a link to the Creative Commons licence, and indicate if changes were made. The images or other third party material in this article are included in the article's Creative Commons licence, unless indicated otherwise in a credit line to the material. If material is not included in the article's Creative Commons licence and your intended use is not permitted by statutory regulation or exceeds the permitted use, you will need to obtain permission directly from the copyright holder. To view a copy of this licence, visit http://creativecommons.org/licenses/by/4.0/.

\section{References}

1. Abdo H, Calvo-Enrique L, Lopez JM, Song J, Zhang M-D, Usoskin D, El Manira A, Adameyko I, Hjerling-Leffler J, Ernfors P (2019) Specialized cutaneous Schwann cells initiate pain sensation. Science 365:695-699. https://doi.org/10.1126/scien ce.aax6452

2. Adriaensen H, Gybels J, Handwerker HO, Van Hees J (1984) Nociceptor discharges and sensations due to prolonged noxious mechanical stimulation - a paradox. Human Neurobiol 3:53-58

3. Akopian AN, Sivilotti L, Wood JN (1996) A tetrodotoxin-resistant voltage-gated sodium channel expressed by sensory neurons. Nature 379:257-262. https://doi.org/10.1038/379257a0

4. Albuisson J, Murthy SE, Bandell M, Coste B, Louis-Dit-Picard H, Mathur J, Fénéant-Thibault M, Tertian G, de Jaureguiberry J-P, Syfuss P-Y, Cahalan S, Garçon L, Toutain F, Simon Rohrlich P, Delaunay J, Picard V, Jeunemaitre X, Patapoutian A (2013) Dehydrated hereditary stomatocytosis linked to gain-of-function mutations in mechanically activated PIEZO1 ion channels. Nat Commun 4:1884. https://doi.org/10.1038/ncomms2899

5. Alcaino C, Knutson KR, Treichel AJ, Yildiz G, Strege PR, Linden DR, Li JH, Leiter AB, Szurszewski JH, Farrugia G, Beyder A (2018) A population of gut epithelial enterochromaffin cells is mechanosensitive and requires Piezo2 to convert force into serotonin release. Proc Natl Acad Sci U S A 115:E7632-E7641. https://doi.org/10.1073/pnas.1804938115

6. Andersson DA, Filipović MR, Gentry C, Eberhardt M, Vastani N, Leffler A, Reeh P, Bevan S (2015) Streptozotocin stimulates the ion channel TRPA1 directly: involvement of peroxynitrite. J Biol Chem 290:15185-15196. https://doi.org/10.1074/jbc.M115. 644476

7. Andersson DA, Gentry C, Light E, Vastani N, Vallortigara J, Bierhaus A, Fleming T, Bevan S (2013) Methylglyoxal evokes pain by stimulating TRPA1. PloS One 8:e77986. https://doi.org/ 10.1371/journal.pone.0077986

8. Andersson DA, Gentry C, Moss S, Bevan S (2008) Transient receptor potential $\mathrm{A} 1$ is a sensory receptor for multiple products of oxidative stress. J Neurosci Off J Soc Neurosci 28:2485-2494. https://doi.org/10.1523/JNEUROSCI.5369-07.2008

9. Babes A, Sauer SK, Moparthi L, Kichko TI, Neacsu C, Namer B, Filipovic M, Zygmunt PM, Reeh PW, Fischer MJM (2016) 
Photosensitization in porphyrias and photodynamic therapy involves TRPA1 and TRPV1. J Neurosci Off J Soc Neurosci 36:5264-5278. https://doi.org/10.1523/JNEUROSCI.4268-15. 2016

10. Baccaglini PI, Hogan PG (1983) Some rat sensory neurons in culture express characteristics of differentiated pain sensory cells. Proc Natl Acad Sci U S A 80:594-598. https://doi.org/10. 1073/pnas.80.2.594

11. Bandell M, Story GM, Hwang SW, Viswanath V, Eid SR, Petrus MJ, Earley TJ, Patapoutian A (2004) Noxious cold ion channel TRPA1 is activated by pungent compounds and bradykinin. Neuron 41:849-857. https://doi.org/10.1016/s0896-6273(04)00150-3

12. Bautista DM, Siemens J, Glazer JM, Tsuruda PR, Basbaum AI, Stucky CL, Jordt S-E, Julius D (2007) The menthol receptor TRPM8 is the principal detector of environmental cold. Nature 448:204-208. https://doi.org/10.1038/nature05910

13. Baxter SL, Keenan WT, Athanas AJ, Proudfoot JA, Zangwill LM, Ayyagari R, Liebmann JM, Girkin CA, Patapoutian A, Weinreb RN (2020) Investigation of associations between Piezo1 mechanoreceptor gain-of-function variants and glaucoma-related phenotypes in humans and mice. Sci Rep 10:19013. https://doi. org/10.1038/s41598-020-76026-0

14. Bellono NW, Leitch DB, Julius D (2017) Molecular basis of ancestral vertebrate electroreception. Nature 543:391-396. https://doi.org/10.1038/nature21401

15. Bellono NW, Leitch DB, Julius D (2018) Molecular tuning of electroreception in sharks and skates. Nature 558:122-126. https://doi.org/10.1038/s41586-018-0160-9

16. Bellono NW, Oancea E (2013) UV light phototransduction depolarizes human melanocytes. Channels Austin Tex 7:243-248. https://doi.org/10.4161/chan.25322

17. Bernardini N, Neuhuber W, Reeh PW, Sauer SK (2004) Morphological evidence for functional capsaicin receptor expression and calcitonin gene-related peptide exocytosis in isolated peripheral nerve axons of the mouse. Neuroscience 126:585-590. https:// doi.org/10.1016/j.neuroscience.2004.03.017

18. Bessou P, Perl ER (1969) Response of cutaneous sensory units with unmyelinated fibers to noxious stimuli. J Neurophysiol 32:1025-1043

19. Bevan S, Szolcsányi J (1990) Sensory neuron-specific actions of capsaicin: mechanisms and applications. Trends Pharmacol Sci 11:330-333. https://doi.org/10.1016/0165-6147(90)90237-3

20. Bhattacharya MRC, Bautista DM, Wu K, Haeberle H, Lumpkin EA, Julius D (2008) Radial stretch reveals distinct populations of mechanosensitive mammalian somatosensory neurons. Proc Natl Acad Sci U S A 105:20015-20020. https://doi.org/10.1073/ pnas.0810801105

21. Bohlen CJ, Chesler AT, Sharif-Naeini R, Medzihradszky KF, Zhou S, King D, Sánchez EE, Burlingame AL, Basbaum AI, Julius D (2011) A heteromeric Texas coral snake toxin targets acid-sensing ion channels to produce pain. Nature 479:410-414. https://doi.org/10.1038/nature10607

22. Bohlen CJ, Priel A, Zhou S, King D, Siemens J, Julius D (2010) A bivalent tarantula toxin activates the capsaicin receptor, TRPV1, by targeting the outer pore domain. Cell 141:834-845. https://doi.org/10.1016/j.cell.2010.03.052

23. Brohawn SG, Campbell EB, MacKinnon R (2014) Physical mechanism for gating and mechanosensitivity of the human TRAAK K+ channel. Nature 516:126-130. https://doi.org/10. 1038/nature14013

24. Brohawn SG, Su Z, MacKinnon R (2014) Mechanosensitivity is mediated directly by the lipid membrane in TRAAK and TREK1 K+ channels. Proc Natl Acad Sci U S A 111:3614-3619. https:// doi.org/10.1073/pnas.1320768111
25. Cahalan SM, Lukacs V, Ranade SS, Chien S, Bandell M, Patapoutian A (2015) Piezo1 links mechanical forces to red blood cell volume. eLife 4 https://doi.org/10.7554/eLife.07370

26. Cao E, Cordero-Morales JF, Liu B, Qin F, Julius D (2013) TRPV1 channels are intrinsically heat sensitive and negatively regulated by phosphoinositide lipids. Neuron 77:667-679. https://doi.org/10.1016/j.neuron.2012.12.016

27. Cao E, Liao M, Cheng Y, Julius D (2013) TRPV1 structures in distinct conformations reveal activation mechanisms. Nature 504:113-118. https://doi.org/10.1038/nature12823

28. Carlier EW (1909) Allyl isothiocyanate: some aspects of its physiological action. Biochem J 4:107-116. https://doi.org/10. 1042/bj0040107

29. Case LK, Liljencrantz J, Madian N, Necaise A, Tubbs J, McCall M, Bradson ML, Szczot M, Pitcher MH, Ghitani N, Frangos E, Cole J, Bharucha-Goebel D, Saade D, Ogata T, Donkervoort S, Foley AR, Bönnemann CG, Olausson H, Bushnell MC, Chesler AT (2021) Innocuous pressure sensation requires A-type afferents but not functional PIEZO2 channels in humans. Nat Commun 12:657. https://doi.org/10.1038/ s41467-021-20939-5

30. Caterina MJ (2021) How do you feel? A warm and touching 2021 Nobel tribute. J Clin Invest e156587 https://doi.org/10. $1172 / \mathrm{JCI} 156587$

31. Caterina MJ, Leffler A, Malmberg AB, Martin WJ, Trafton J, Petersen-Zeitz KR, Koltzenburg M, Basbaum AI, Julius D (2000) Impaired nociception and pain sensation in mice lacking the capsaicin receptor. Science 288:306-313

32. Caterina MJ, Rosen TA, Tominaga M, Brake AJ, Julius D (1999) A capsaicin-receptor homologue with a high threshold for noxious heat. Nature 398:436-441. https://doi.org/10.1038/18906

33. Caterina MJ, Schumacher MA, Tominaga M, Rosen TA, Levine JD, Julius D (1997) The capsaicin receptor: a heat-activated ion channel in the pain pathway. Nature 389:816-824. https://doi. org/10.1038/39807

34. Cattaruzza F, Johnson C, Leggit A, Grady E, Schenk AK, Cevikbas F, Cedron W, Bondada S, Kirkwood R, Malone B, Steinhoff M, Bunnett N, Kirkwood KS (2013) Transient receptor potential ankyrin 1 mediates chronic pancreatitis pain in mice. Am $\mathbf{J}$ Physiol Gastrointest Liver Physiol 304:G1002-1012. https://doi. org/10.1152/ajpgi.00005.2013

35. Cesare P, McNaughton P (1996) A novel heat-activated current in nociceptive neurons and its sensitization by bradykinin. Proc Natl Acad Sci U S A 93:15435-15439. https://doi.org/10.1073/ pnas.93.26.15435

36. Chen CC, Akopian AN, Sivilotti L, Colquhoun D, Burnstock G, Wood JN (1995) A P2X purinoceptor expressed by a subset of sensory neurons. Nature 377:428-431. https://doi.org/10.1038/ $377428 \mathrm{a} 0$

37. Chen Y, Wang Z-L, Yeo M, Zhang Q-J, López-Romero AE, Ding H-P, Zhang X, Zeng Q, Morales-Lázaro SL, Moore C, Jin Y-A, Yang H-H, Morstein J, Bortsov A, Krawczyk M, Lammert F, Abdelmalek M, Diehl AM, Milkiewicz P, Kremer AE, Zhang JY, Nackley A, Reeves TE, Ko M-C, Ji R-R, Rosenbaum T, Liedtke W (2021) Epithelia-sensory neuron cross talk underlies cholestatic itch induced by lysophosphatidylcholine. Gastroenterology 161:301-317.e16. https://doi.org/10.1053/j.gastro.2021.03.049

38. Chesler AT, Szczot M, Bharucha-Goebel D, Čeko M, Donkervoort S, Laubacher C, Hayes LH, Alter K, Zampieri C, Stanley C, Innes AM, Mah JK, Grosmann CM, Bradley N, Nguyen D, Foley AR, Le Pichon CE, Bönnemann CG (2016) The role of PIEZO2 in human mechanosensation. N Engl J Med 375:1355-1364. https://doi.org/10.1056/NEJMoa1602812

39. Clemmensen C, Jall S, Kleinert M, Quarta C, Gruber T, Reber J, Sachs S, Fischer K, Feuchtinger A, Karlas A, Simonds SE, Grandl G, Loher D, Sanchez-Quant E, Keipert S, Jastroch M, 
Hofmann SM, Nascimento EBM, Schrauwen P, Ntziachristos V, Cowley MA, Finan B, Müller TD, Tschöp MH (2018) Coordinated targeting of cold and nicotinic receptors synergistically improves obesity and type 2 diabetes. Nat Commun 9:4304. https://doi.org/10.1038/s41467-018-06769-y

40. Conklin BR, Farfel Z, Lustig KD, Julius D, Bourne HR (1993) Substitution of three amino acids switches receptor specificity of Gq alpha to that of Gi alpha. Nature 363:274-276. https://doi. org/10.1038/363274a0

41. Coste B, Mathur J, Schmidt M, Earley TJ, Ranade S, Petrus MJ, Dubin AE, Patapoutian A (2010) Piezo1 and Piezo2 are essential components of distinct mechanically activated cation channels. Science 330:55-60. https://doi.org/10.1126/science.1193270

42. Cruz F, Guimarães M, Silva C, Rio ME, Coimbra A, Reis M (1997) Desensitization of bladder sensory fibers by intravesical capsaicin has long lasting clinical and urodynamic effects in patients with hyperactive or hypersensitive bladder dysfunction. J Urol 157:585-589

43. Csekő K, Beckers B, Keszthelyi D, Helyes Z (2019) Role of TRPV1 and TRPA1 ion channels in inflammatory bowel diseases: potential therapeutic targets? Pharm Basel Switz 12:E48. https://doi.org/10.3390/ph12020048

44. Davis JB, Gray J, Gunthorpe MJ, Hatcher JP, Davey PT, Overend P, Harries MH, Latcham J, Clapham C, Atkinson K, Hughes SA, Rance K, Grau E, Harper AJ, Pugh PL, Rogers DC, Bingham S, Randall A, Sheardown SA (2000) Vanilloid receptor-1 is essential for inflammatory thermal hyperalgesia. Nature 405:183-187. https://doi.org/10.1038/35012076

45. Dubin AE, Murthy S, Lewis AH, Brosse L, Cahalan SM, Grandl J, Coste B, Patapoutian A (2017) Endogenous Piezo1 can confound mechanically activated channel identification and characterization. Neuron 94:266-270.e3. https://doi.org/ 10.1016/j.neuron.2017.03.039

46. Dubin AE, Schmidt M, Mathur J, Petrus MJ, Xiao B, Coste B, Patapoutian A (2012) Inflammatory signals enhance piezo2mediated mechanosensitive currents. Cell Rep 2:511-517. https://doi.org/10.1016/j.celrep.2012.07.014

47. Eberhardt M, Dux M, Namer B, Miljkovic J, Cordasic N, Will C, Kichko TI, de la Roche J, Fischer M, Suárez SA, Bikiel D, Dorsch K, Leffler A, Babes A, Lampert A, Lennerz JK, Jacobi J, Martí MA, Doctorovich F, Högestätt ED, Zygmunt PM, Ivanovic-Burmazovic I, Messlinger K, Reeh P, Filipovic MR (2014) H2S and NO cooperatively regulate vascular tone by activating a neuroendocrine HNO-TRPA1-CGRP signalling pathway. Nat Commun 5:4381. https://doi.org/10.1038/ncomm s5381

48. Eberhardt MJ, Filipovic MR, Leffler A, de la Roche J, Kistner K, Fischer MJ, Fleming T, Zimmermann K, Ivanovic-Burmazovic I, Nawroth PP, Bierhaus A, Reeh PW, Sauer SK (2012) Methylglyoxal activates nociceptors through transient receptor potential channel A1 (TRPA1): a possible mechanism of metabolic neuropathies. J Biol Chem 287:28291-28306. https://doi.org/10. 1074/jbc.M111.328674

49. Emrick JJ, Mathur A, Wei J, Gracheva EO, Gronert K, Rosenblum MD, Julius D (2018) Tissue-specific contributions of Tmem79 to atopic dermatitis and mast cell-mediated histaminergic itch. Proc Natl Acad Sci U S A 115:E12091-E12100. https:// doi.org/10.1073/pnas.1814132115

50. Engel MA, Khalil M, Mueller-Tribbensee SM, Becker C, Neuhuber WL, Neurath MF, Reeh PW (2012) The proximodistal aggravation of colitis depends on substance P released from TRPV1expressing sensory neurons. J Gastroenterol 47:256-265. https:// doi.org/10.1007/s00535-011-0495-6

51. Engel MA, Khalil M, Siklosi N, Mueller-Tribbensee SM, Neuhuber WL, Neurath MF, Becker C, Reeh PW (2012) Opposite effects of substance $\mathrm{P}$ and calcitonin gene-related peptide in oxazolone colitis. Dig Liver Dis Off J Ital Soc Gastroenterol Ital Assoc Study Liver 44:24-29. https://doi.org/10.1016/j.dld.2011. 08.030

52. Engel MA, Leffler A, Niedermirtl F, Babes A, Zimmermann K, Filipović MR, Izydorczyk I, Eberhardt M, Kichko TI, Mueller-Tribbensee SM, Khalil M, Siklosi N, Nau C, IvanovićBurmazović I, Neuhuber WL, Becker C, Neurath MF, Reeh PW (2011) TRPA1 and substance P mediate colitis in mice. Gastroenterology 141:1346-1358. https://doi.org/10.1053/j.gastro. 2011.07.002

53. England LJ, Imperial J, Jacobsen R, Craig AG, Gulyas J, Akhtar M, Rivier J, Julius D, Olivera BM (1998) Inactivation of a serotonin-gated ion channel by a polypeptide toxin from marine snails. Science 281:575-578. https://doi.org/10.1126/science.281.5376. 575

54. Fischer MJM, Btesh J, McNaughton PA (2013) Disrupting sensitization of transient receptor potential vanilloid subtype 1 inhibits inflammatory hyperalgesia. J Neurosci Off J Soc Neurosci 33:7407-7414. https://doi.org/10.1523/JNEUROSCI. 3721-12.2013

55. Forster C, Anton F, Reeh PW, Weber E, Handwerker HO (1988) Measurement of the analgesic effects of aspirin with a new experimental algesimetric procedure. Pain 32:215-222. https://doi.org/10.1016/0304-3959(88)90070-X

56. François A, Schüetter N, Laffray S, Sanguesa J, Pizzoccaro A, Dubel S, Mantilleri A, Nargeot J, Noël J, Wood JN, Moqrich A, Pongs O, Bourinet E (2015) The low-threshold calcium channel Cav3.2 determines low-threshold mechanoreceptor function. Cell Rep 10:370-382. https://doi.org/10.1016/j.celrep.2014.12.042

57. Fricke TC, Echtermeyer F, Zielke J, de la Roche J, Filipovic MR, Claverol S, Herzog C, Tominaga M, Pumroy RA, Moiseenkova-Bell VY, Zygmunt PM, Leffler A, Eberhardt MJ (2019) Oxidation of methionine residues activates the highthreshold heat-sensitive ion channel TRPV2. Proc Natl Acad Sci U S A 116:24359-24365. https://doi.org/10.1073/pnas. 1904332116

58. Fujino K, Takami Y, de la Fuente SG, Ludwig KA, Mantyh CR (2004) Inhibition of the vanilloid receptor subtype-1 attenuates TNBS-colitis. J Gastrointest Surg Off J Soc Surg Aliment Tract 8:842-847; discussion 847-848 https://doi.org/10.1016/j.gassur. 2004.07.011

59. Gavva NR, Sandrock R, Arnold GE, Davis M, Lamas E, Lindvay C, Li C-M, Smith B, Backonja M, Gabriel K, Vargas G (2019) Reduced TRPM8 expression underpins reduced migraine risk and attenuated cold pain sensation in humans. Sci Rep 9:19655. https://doi.org/10.1038/s41598-019-56295-0

60. Ge J, Li W, Zhao Q, Li N, Chen M, Zhi P, Li R, Gao N, Xiao B, Yang M (2015) Architecture of the mammalian mechanosensitive Piezo1 channel. Nature 527:64-69. https://doi.org/10.1038/natur e15247

61. Gentry C, Andersson DA, Bevan S (2015) TRPA1 mediates the hypothermic action of acetaminophen. Sci Rep 5:12771. https:// doi.org/10.1038/srep12771

62. Güler AD, Lee H, Iida T, Shimizu I, Tominaga M, Caterina M (2002) Heat-evoked activation of the ion channel, TRPV4. J Neurosci Off J Soc Neurosci 22:6408-6414 (20026679)

63. Guo YR, MacKinnon R (2017) Structure-based membrane dome mechanism for Piezo mechanosensitivity. eLife 6:e33660. https:// doi.org/10.7554/eLife.33660

64. Hammond GRV, Fischer MJ, Anderson KE, Holdich J, Koteci A, Balla T, Irvine RF (2012) PI4P and PI(4,5)P2 are essential but independent lipid determinants of membrane identity. Science 337:727-730. https://doi.org/10.1126/science.1222483

65. Hanack C, Moroni M, Lima WC, Wende H, Kirchner M, Adelfinger L, Schrenk-Siemens K, Tappe-Theodor A, Wetzel C, Kuich 
PH, Gassmann M, Roggenkamp D, Bettler B, Lewin GR, Selbach M, Siemens J (2015) GABA blocks pathological but not acute TRPV1 pain signals. Cell 160:759-770. https://doi.org/10. 1016/j.cell.2015.01.022

66. Handler A, Ginty DD (2021) The mechanosensory neurons of touch and their mechanisms of activation. Nat Rev Neurosci 22:521-537. https://doi.org/10.1038/s41583-021-00489-x

67. Handwerker HO, Anton F, Reeh PW (1987) Discharge patterns of afferent cutaneous nerve fibers from the rat's tail during prolonged noxious mechanical stimulation. Exp Brain Res 65:493504. https://doi.org/10.1007/BF00235972

68. Hardie RC, Franze K (2012) Photomechanical responses in Drosophila photoreceptors. Science 338:260-263. https://doi.org/10. $1126 /$ science. 1222376

69. Heber S, Ciotu CI, Hartner G, Gold-Binder M, Ninidze N, Gleiss A, Kress H-G, Fischer MJM (2020) TRPV1 antagonist BCTC inhibits pH 6.0-induced pain in human skin. Pain 161:15321541. https://doi.org/10.1097/j.pain.0000000000001848

70. Heber S, Fischer MJM (2019) Non-analgesic symptomatic or disease-modifying potential of TRPA1. Med Sci Basel Switz 7:E99. https://doi.org/10.3390/medsci7100099

71. Hill K, Schaefer M (2007) TRPA1 is differentially modulated by the amphipathic molecules trinitrophenol and chlorpromazine. J Biol Chem 282:7145-7153. https://doi.org/10.1074/jbc.M6096 00200

72. Hill K, Schaefer M (2009) Ultraviolet light and photosensitising agents activate TRPA1 via generation of oxidative stress. Cell Calcium 45:155-164. https://doi.org/10.1016/j.ceca.2008.08.001

73. Hoffmann T, De Col R, Messlinger K, Reeh PW, Weidner C (2015) Mice and rats differ with respect to activity-dependent slowing of conduction velocity in the saphenous peripheral nerve. Neurosci Lett 592:12-16. https://doi.org/10.1016/j.neulet. 2015.02.057

74. Hoffmann T, Kistner K, Miermeister F, Winkelmann R, Wittmann J, Fischer MJM, Weidner C, Reeh PW (2013) TRPA1 and TRPV1 are differentially involved in heat nociception of mice. Eur J Pain Lond Engl 17:1472-1482. https://doi.org/10.1002/j. 1532-2149.2013.00331.x

75. Hoffmann T, Sauer SK, Horch RE, Reeh PW (2008) Sensory transduction in peripheral nerve axons elicits ectopic action potentials. J Neurosci Off J Soc Neurosci 28:6281-6284. https:// doi.org/10.1523/JNEUROSCI.1627-08.2008

76. Holt JR, Zeng W-Z, Evans EL, Woo S-H, Ma S, Abuwarda H, Loud M, Patapoutian A, Pathak MM (2021) Spatiotemporal dynamics of PIEZO1 localization controls keratinocyte migration during wound healing. eLife 10:e65415 https://doi.org/10. 7554/eLife.65415

77. Hoshijima H, Hunt M, Nagasaka H, Yaksh T (2021) Systematic review of systemic and neuraxial effects of acetaminophen in preclinical models of nociceptive processing. J Pain Res 14:35213552. https://doi.org/10.2147/JPR.S308028

78. Hu J, Milenkovic N, Lewin GR (2006) The high threshold mechanotransducer: a status report. Pain 120:3-7. https://doi.org/10. 1016/j.pain.2005.11.002

79. Huang SM, Li X, Yu Y, Wang J, Caterina MJ (2011) TRPV3 and TRPV4 ion channels are not major contributors to mouse heat sensation. Mol Pain 7:37. https://doi.org/10.1186/ 1744-8069-7-37

80. Iwata Y, Matsumura T (2019) Blockade of TRPV2 is a novel therapy for cardiomyopathy in muscular dystrophy. Int J Mol Sci 20:E3844. https://doi.org/10.3390/ijms20163844

81. Jancsó N, Jancsó-Gábor A, Szolcsányi J (1967) Direct evidence for neurogenic inflammation and its prevention by denervation and by pretreatment with capsaicin. Br J Pharmacol Chemother 31:138-151. https://doi.org/10.1111/j.1476-5381.1967.tb01984.x
82. Jordt S-E, Bautista DM, Chuang H-H, McKemy DD, Zygmunt PM, Högestätt ED, Meng ID, Julius D (2004) Mustard oils and cannabinoids excite sensory nerve fibres through the TRP channel ANKTM1. Nature 427:260-265. https://doi.org/10.1038/ nature 02282

83. Jordt S-E, Julius D (2002) Molecular basis for species-specific sensitivity to "hot" chili peppers. Cell 108:421-430. https://doi. org/10.1016/s0092-8674(02)00637-2

84. Julius D, MacDermott AB, Axel R, Jessell TM (1988) Molecular characterization of a functional cDNA encoding the serotonin $1 \mathrm{c}$ receptor. Science 241:558-564. https://doi.org/10.1126/science. 3399891

85. Katanosaka K, Takatsu S, Mizumura K, Naruse K, Katanosaka Y (2018) TRPV2 is required for mechanical nociception and the stretch-evoked response of primary sensory neurons. Sci Rep 8:16782. https://doi.org/10.1038/s41598-018-35049-4

86. Kefauver JM, Saotome K, Dubin AE, Pallesen J, Cottrell CA, Cahalan SM, Qiu Z, Hong G, Crowley CS, Whitwam T, Lee W-H, Ward AB, Patapoutian A (2018) Structure of the human volume regulated anion channel. eLife 7:e38461 https://doi.org/ 10.7554/eLife.38461

87. Kichko TI, Niedermirtl F, Leffler A, Reeh PW (2015) Irritant volatile anesthetics induce neurogenic inflammation through TRPA1 and TRPV1 channels in the isolated mouse trachea. Anesth Analg 120:467-471. https://doi.org/10.1213/ANE.00000 00000000568

88. Kindt KS, Viswanath V, Macpherson L, Quast K, Hu H, Patapoutian A, Schafer WR (2007) Caenorhabditis elegans TRPA-1 functions in mechanosensation. Nat Neurosci 10:568-577. https://doi org/10.1038/nn1886

89. Kissin I, Szallasi A (2011) Therapeutic targeting of TRPV1 by resiniferatoxin, from preclinical studies to clinical trials. Curr Top Med Chem 11:2159-2170. https://doi.org/10.2174/15680 2611796904924

90. Kistner K, Siklosi N, Babes A, Khalil M, Selescu T, Zimmermann K, Wirtz S, Becker C, Neurath MF, Reeh PW, Engel MA (2016) Systemic desensitization through TRPA1 channels by capsazepine and mustard oil - a novel strategy against inflammation and pain. Sci Rep 6:28621. https://doi.org/10.1038/srep2 8621

91. Koivisto A-P, Belvisi MG, Gaudet R, Szallasi A (2021) Advances in TRP channel drug discovery: from target validation to clinical studies. Nat Rev Drug Discov. https://doi.org/10.1038/ s41573-021-00268-4

92. Kremeyer B, Lopera F, Cox JJ, Momin A, Rugiero F, Marsh S, Woods CG, Jones NG, Paterson KJ, Fricker FR, Villegas A, Acosta N, Pineda-Trujillo NG, Ramírez JD, Zea J, Burley M-W, Bedoya G, Bennett DLH, Wood JN, Ruiz-Linares A (2010) A gain-of-function mutation in TRPA1 causes familial episodic pain syndrome. Neuron 66:671-680. https://doi.org/10.1016/j. neuron.2010.04.030

93. Kress M, Koltzenburg M, Reeh PW, Handwerker HO (1992) Responsiveness and functional attributes of electrically localized terminals of cutaneous C-fibers in vivo and in vitro. J Neurophysiol 68:581-595. https://doi.org/10.1152/jn.1992.68.2.581

94. Kwan KY, Allchorne AJ, Vollrath MA, Christensen AP, Zhang D-S, Woolf CJ, Corey DP (2006) TRPA1 contributes to cold, mechanical, and chemical nociception but is not essential for hair-cell transduction. Neuron 50:277-289. https://doi.org/10. 1016/j.neuron.2006.03.042

95. Lacroix JJ, Botello-Smith WM, Luo Y (2018) Probing the gating mechanism of the mechanosensitive channel Piezo1 with the small molecule Yoda1. Nat Commun 9:2029. https://doi.org/10. 1038/s41467-018-04405-3

96. Liang YF, Haake B, Reeh PW (2001) Sustained sensitization and recruitment of rat cutaneous nociceptors by bradykinin and 
a novel theory of its excitatory action. J Physiol 532:229-239. https://doi.org/10.1111/j.1469-7793.2001.0229g.x

97. Liao M, Cao E, Julius D, Cheng Y (2013) Structure of the TRPV1 ion channel determined by electron cryo-microscopy. Nature 504:107-112. https://doi.org/10.1038/nature12822

98. Liedtke W, Choe Y, Martí-Renom MA, Bell AM, Denis CS, Sali A, Hudspeth AJ, Friedman JM, Heller S (2000) Vanilloid receptor-related osmotically activated channel (VR-OAC), a candidate vertebrate osmoreceptor. Cell 103:525-535

99. Löken LS, Wessberg J, Morrison I, McGlone F, Olausson H (2009) Coding of pleasant touch by unmyelinated afferents in humans. Nat Neurosci 12:547-548. https://doi.org/10.1038/nn. 2312

100. Lustig KD, Shiau AK, Brake AJ, Julius D (1993) Expression cloning of an ATP receptor from mouse neuroblastoma cells. Proc Natl Acad Sci U S A 90:5113-5117. https://doi.org/10. 1073/pnas.90.11.5113

101. Ma S, Cahalan S, LaMonte G, Grubaugh ND, Zeng W, Murthy SE, Paytas E, Gamini R, Lukacs V, Whitwam T, Loud M, Lohia R, Berry L, Khan SM, Janse CJ, Bandell M, Schmedt C, Wengelnik K, Su AI, Honore E, Winzeler EA, Andersen KG, Patapoutian A (2018) Common PIEZO1 allele in African populations causes RBC dehydration and attenuates plasmodium infection. Cell 173:443-455.e12. https://doi.org/10.1016/j.cell.2018.02.047

102. Ma S, Dubin AE, Zhang Y, Mousavi SAR, Wang Y, Coombs AM, Loud M, Andolfo I, Patapoutian A (2021) A role of PIEZO1 in iron metabolism in mice and humans. Cell 184:969-982.e13. https://doi.org/10.1016/j.cell.2021.01.024

103. Mandadi S, Sokabe T, Shibasaki K, Katanosaka K, Mizuno A, Moqrich A, Patapoutian A, Fukumi-Tominaga T, Mizumura K, Tominaga M (2009) TRPV3 in keratinocytes transmits temperature information to sensory neurons via ATP. Pflugers Arch 458:1093-1102. https://doi.org/10.1007/s00424-009-0703-x

104. Maricq AV, Peterson AS, Brake AJ, Myers RM, Julius D (1991) Primary structure and functional expression of the 5HT3 receptor, a serotonin-gated ion channel. Science 254:432-437. https:// doi.org/10.1126/science.1718042

105. Marshall KL, Saade D, Ghitani N, Coombs AM, Szczot M, Keller J, Ogata T, Daou I, Stowers LT, Bönnemann CG, Chesler AT, Patapoutian A (2020) PIEZO2 in sensory neurons and urothelial cells coordinates urination. Nature 588:290-295. https://doi.org/ $10.1038 / \mathrm{s} 41586-020-2830-7$

106. McKemy DD, Neuhausser WM, Julius D (2002) Identification of a cold receptor reveals a general role for TRP channels in thermosensation. Nature 416:52-58. https://doi.org/10.1038/natur e719

107. Meng J, Li Y, Fischer MJM, Steinhoff M, Chen W, Wang J (2021) Th2 modulation of transient receptor potential channels: an unmet therapeutic intervention for atopic dermatitis. Front Immunol 12:696784. https://doi.org/10.3389/fimmu. 2021. 696784

108. Meseguer V, Alpizar YA, Luis E, Tajada S, Denlinger B, Fajardo O, Manenschijn J-A, Fernández-Peña C, Talavera A, Kichko T, Navia B, Sánchez A, Señarís R, Reeh P, Pérez-García MT, López-López JR, Voets T, Belmonte C, Talavera K, Viana F (2014) TRPA1 channels mediate acute neurogenic inflammation and pain produced by bacterial endotoxins. Nat Commun 5:3125. https://doi.org/10.1038/ncomms4125

109. Moehring F, Cowie AM, Menzel AD, Weyer AD, Grzybowski M, Arzua T, Geurts AM, Palygin O, Stucky CL (2018) Keratinocytes mediate innocuous and noxious touch via ATP-P2X4 signaling. eLife 7 https://doi.org/10.7554/eLife.31684

110. Moparthi L, Kichko TI, Eberhardt M, Högestätt ED, Kjellbom P, Johanson U, Reeh PW, Leffler A, Filipovic MR, Zygmunt PM (2016) Human TRPA1 is a heat sensor displaying intrinsic
U-shaped thermosensitivity. Sci Rep 6:28763. https://doi.org/10. 1038/srep28763

111. Moparthi L, Zygmunt PM (2020) Human TRPA1 is an inherently mechanosensitive bilayer-gated ion channel. Cell Calcium 91:102255. https://doi.org/10.1016/j.ceca.2020.102255

112. Moqrich A, Earley TJ, Watson J, Andahazy M, Backus C, Martin-Zanca D, Wright DE, Reichardt LF, Patapoutian A (2004) Expressing TrkC from the TrkA locus causes a subset of dorsal root ganglia neurons to switch fate. Nat Neurosci 7:812-818. https://doi.org/10.1038/nn1283

113. Mou J, Paillard F, Turnbull B, Trudeau J, Stoker M, Katz NP (2013) Efficacy of Qutenza ${ }^{\circledR}$ (capsaicin) 8\% patch for neuropathic pain: a meta-analysis of the Qutenza Clinical Trials Database. Pain 154:1632-1639. https://doi.org/10.1016/j.pain.2013. 04.044

114. Mueller-Tribbensee SM, Karna M, Khalil M, Neurath MF, Reeh PW, Engel MA (2015) Differential contribution of TRPA1, TRPV4 and TRPM8 to colonic nociception in mice. PloS One 10:e0128242. https://doi.org/10.1371/journal.pone.0128242

115. Munaron L (2011) Shuffling the cards in signal transduction: calcium, arachidonic acid and mechanosensitivity. World J Biol Chem 2:59-66. https://doi.org/10.4331/wjbc.v2.i4.59

116. Murthy SE, Loud MC, Daou I, Marshall KL, Schwaller F, Kühnemund J, Francisco AG, Keenan WT, Dubin AE, Lewin GR, Patapoutian A (2018) The mechanosensitive ion channel Piezo2 mediates sensitivity to mechanical pain in mice. Sci Transl Med 10https://doi.org/10.1126/scitranslmed.aat9897

117. Naert R, Talavera A, Startek JB, Talavera K (2020) TRPA1 gene variants hurting our feelings. Pflugers Arch 472:953-960. https:// doi.org/10.1007/s00424-020-02397-y

118. Nagi SS, Marshall AG, Makdani A, Jarocka E, Liljencrantz J, Ridderström M, Shaikh S, O'Neill F, Saade D, Donkervoort S, Foley AR, Minde J, Trulsson M, Cole J, Bönnemann CG, Chesler AT, Bushnell MC, McGlone F, Olausson H (2019) An ultrafast system for signaling mechanical pain in human skin. Sci Adv 5:eaaw1297 https://doi.org/10.1126/sciadv.aaw1297

119. Nassini R, Fusi C, Materazzi S, Coppi E, Tuccinardi T, Marone IM, De Logu F, Preti D, Tonello R, Chiarugi A, Patacchini R, Geppetti P, Benemei S (2015) The TRPA1 channel mediates the analgesic action of dipyrone and pyrazolone derivatives. Br J Pharmacol 172:3397-3411. https://doi.org/10.1111/bph.13129

120. Noël J, Zimmermann K, Busserolles J, Deval E, Alloui A, Diochot S, Guy N, Borsotto M, Reeh P, Eschalier A, Lazdunski M (2009) The mechano-activated K+ channels TRAAK and TREK-1 control both warm and cold perception. EMBO J 28:1308-1318. https://doi.org/10.1038/emboj.2009.57

121. Nonomura K, Woo S-H, Chang RB, Gillich A, Qiu Z, Francisco AG, Ranade SS, Liberles SD, Patapoutian A (2017) Piezo2 senses airway stretch and mediates lung inflation-induced apnoea. Nature 541:176-181. https://doi.org/10.1038/natur e20793

122. Obreja O, Rukwied R, Nagler L, Schmidt M, Schmelz M, Namer B (2018) Nerve growth factor locally sensitizes nociceptors in human skin. Pain 159:416-426. https://doi.org/10.1097/j.pain. 0000000000001108

123. Olmsted JB, Carlson K, Klebe R, Ruddle F, Rosenbaum J (1970) Isolation of microtubule protein from cultured mouse neuroblastoma cells. Proc Natl Acad Sci U S A 65:129-136. https://doi. org/10.1073/pnas.65.1.129

124. Osteen JD, Herzig V, Gilchrist J, Emrick JJ, Zhang C, Wang X, Castro J, Garcia-Caraballo S, Grundy L, Rychkov GY, Weyer AD, Dekan Z, Undheim EAB, Alewood P, Stucky CL, Brierley SM, Basbaum AI, Bosmans F, King GF, Julius D (2016) Selective spider toxins reveal a role for the Nav1.1 channel in 
mechanical pain. Nature 534:494-499. https://doi.org/10.1038/ nature 17976

125. Paricio-Montesinos R, Schwaller F, Udhayachandran A, Rau F, Walcher J, Evangelista R, Vriens J, Voets T, Poulet JFA, Lewin GR (2020) The sensory coding of warm perception. Neuron 106:830-841.e3. https://doi.org/10.1016/j.neuron.2020.02.035

126. Park U, Vastani N, Guan Y, Raja SN, Koltzenburg M, Caterina MJ (2011) TRP vanilloid 2 knock-out mice are susceptible to perinatal lethality but display normal thermal and mechanical nociception. J Neurosci Off J Soc Neurosci 31:11425-11436. https://doi.org/10.1523/JNEUROSCI.1384-09.2011

127. Parra A, Madrid R, Echevarria D, del Olmo S, Morenilla-Palao C, Acosta MC, Gallar J, Dhaka A, Viana F, Belmonte C (2010) Ocular surface wetness is regulated by TRPM8-dependent cold thermoreceptors of the cornea. Nat Med 16:1396-1399. https:// doi.org/10.1038/nm.2264

128. Patapoutian A, Backus C, Kispert A, Reichardt LF (1999) Regulation of neurotrophin-3 expression by epithelial-mesenchymal interactions: the role of Wnt factors. Science 283:1180-1183. https://doi.org/10.1126/science.283.5405.1180

129. Patapoutian A, Miner JH, Lyons GE, Wold B (1993) Isolated sequences from the linked Myf-5 and MRF4 genes drive distinct patterns of muscle-specific expression in transgenic mice. Dev Camb Engl 118:61-69

130. Patapoutian A, Wold BJ, Wagner RA (1995) Evidence for developmentally programmed transdifferentiation in mouse esophageal muscle. Science 270:1818-1821. https://doi.org/10.1126/ science. 270.5243 .1818

131. Peier AM, Moqrich A, Hergarden AC, Reeve AJ, Andersson DA, Story GM, Earley TJ, Dragoni I, McIntyre P, Bevan S, Patapoutian A (2002) A TRP channel that senses cold stimuli and menthol. Cell 108:705-715. https://doi.org/10.1016/s0092-8674(02) 00652-9

132. Petrus M, Peier AM, Bandell M, Hwang SW, Huynh T, Olney N, Jegla T, Patapoutian A (2007) A role of TRPA1 in mechanical hyperalgesia is revealed by pharmacological inhibition. Mol Pain 3:40. https://doi.org/10.1186/1744-8069-3-40

133. Prato V, Taberner FJ, Hockley JRF, Callejo G, Arcourt A, Tazir B, Hammer L, Schad P, Heppenstall PA, Smith ES, Lechner SG (2017) Functional and molecular characterization of mechanoinsensitive "silent" nociceptors. Cell Rep 21:3102-3115. https:// doi.org/10.1016/j.celrep.2017.11.066

134. Proudfoot CJ, Garry EM, Cottrell DF, Rosie R, Anderson H, Robertson DC, Fleetwood-Walker SM, Mitchell R (2006) Analgesia mediated by the TRPM8 cold receptor in chronic neuropathic pain. Curr Biol CB 16:1591-1605. https://doi.org/10. 1016/j.cub.2006.07.061

135. Qiu Z, Dubin AE, Mathur J, Tu B, Reddy K, Miraglia LJ, Reinhardt J, Orth AP, Patapoutian A (2014) SWELL1, a plasma membrane protein, is an essential component of volume-regulated anion channel. Cell 157:447-458. https://doi.org/10.1016/j.cell. 2014.03.024

136. Quallo T, Vastani N, Horridge E, Gentry C, Parra A, Moss S, Viana F, Belmonte C, Andersson DA, Bevan S (2015) TRPM8 is a neuronal osmosensor that regulates eye blinking in mice. Nat Commun 6:7150. https://doi.org/10.1038/ncomms8150

137. Ramos MTA, PharmD, MPH, Atkinson TJ, PharmD, BCPS, CPE Inside the Potential of Nerve Growth Factor Antagonists. In: Pract. Pain Manag. https://www.practicalpainmanagement. $\mathrm{com} /$ treatments/pharmacological/non-opioids/analgesics-futureinside-potential-nerve-growth-factor. Accessed 12 Dec 2021

138. Ranade SS, Qiu Z, Woo S-H, Hur SS, Murthy SE, Cahalan SM, Xu J, Mathur J, Bandell M, Coste B, Li Y-SJ, Chien S, Patapoutian A (2014) Piezo1, a mechanically activated ion channel, is required for vascular development in mice. Proc Natl Acad Sci U S A 111:10347-10352. https://doi.org/10.1073/pnas.1409233111
139. Ranade SS, Woo S-H, Dubin AE, Moshourab RA, Wetzel C, Petrus M, Mathur J, Bégay V, Coste B, Mainquist J, Wilson AJ, Francisco AG, Reddy K, Qiu Z, Wood JN, Lewin GR, Patapoutian A (2014) Piezo2 is the major transducer of mechanical forces for touch sensation in mice. Nature 516:121-125. https://doi.org/ 10.1038/nature13980

140. Reeh PW, Bayer J, Kocher L, Handwerker HO (1987) Sensitization of nociceptive cutaneous nerve fibers from the rat's tail by noxious mechanical stimulation. Exp Brain Res 65:505-512. https://doi.org/10.1007/BF00235973

141. Reimúndez A, Fernández-Peña C, García G, Fernández R, Ordás P, Gallego R, Pardo-Vazquez JL, Arce V, Viana F, Señarís R (2018) Deletion of the cold thermoreceptor TRPM8 increases heat loss and food intake leading to reduced body temperature and obesity in mice. J Neurosci Off J Soc Neurosci 38:36433656. https://doi.org/10.1523/JNEUROSCI.3002-17.2018

142. de la Roche J, Eberhardt MJ, Klinger AB, Stanslowsky N, Wegner F, Koppert W, Reeh PW, Lampert A, Fischer MJM, Leffler A (2013) The molecular basis for species-specific activation of human TRPA1 protein by protons involves poorly conserved residues within transmembrane domains 5 and 6. J Biol Chem 288:20280-20292. https://doi.org/10.1074/jbc.M113.479337

143. Roh J, Hwang S-M, Lee S-H, Lee K, Kim YH, Park C-K (2020) Functional expression of Piezo1 in dorsal root ganglion (DRG) neurons. Int J Mol Sci 21:E3834. https://doi.org/10.3390/ijms2 1113834

144. Rosenberger DC, Binzen U, Treede R-D, Greffrath W (2020) The capsaicin receptor TRPV1 is the first line defense protecting from acute non damaging heat: a translational approach. J Transl Med 18:28. https://doi.org/10.1186/ s12967-019-02200-2

145. Roza C, Reeh PW (2001) Substance P, calcitonin gene related peptide and PGE2 co-released from the mouse colon: a new model to study nociceptive and inflammatory responses in viscera, in vitro. Pain 93:213-219. https://doi.org/10.1016/S03043959(01)00318-9

146. Rukwied R, Mayer A, Kluschina O, Obreja O, Schley M, Schmelz M (2010) NGF induces non-inflammatory localized and lasting mechanical and thermal hypersensitivity in human skin. Pain 148:407-413. https://doi.org/10.1016/j.pain.2009.11.022

147. Sadler KE, Moehring F, Stucky CL (2020) Keratinocytes contribute to normal cold and heat sensation. eLife 9 https://doi.org/ 10.7554/eLife. 58625

148. Saotome K, Murthy SE, Kefauver JM, Whitwam T, Patapoutian A, Ward AB (2018) Structure of the mechanically activated ion channel Piezo1. Nature 554:481-486. https://doi.org/10.1038/ nature 25453

149. Schenk SA, Dick F, Herzog C, Eberhardt MJ, Leffler A (2019) Active metabolites of dipyrone induce a redox-dependent activation of the ion channels TRPA1 and TRPV1. Pain Rep 4:e720. https://doi.org/10.1097/PR9.0000000000000720

150. Schlegel T, Sauer SK, Handwerker HO, Reeh PW (2004) Responsiveness of C-fiber nociceptors to punctate force-controlled stimuli in isolated rat skin: lack of modulation by inflammatory mediators and flurbiprofen. Neurosci Lett 361:163-167. https://doi.org/10.1016/j.neulet.2003.12.073

151. Schmidt R, Schmelz M, Weidner C, Handwerker HO, Torebjörk HE (2002) Innervation territories of mechano-insensitive $C$ nociceptors in human skin. J Neurophysiol 88:1859-1866. https://doi. org/10.1152/jn.2002.88.4.1859

152. Seal RP, Wang X, Guan Y, Raja SN, Woodbury CJ, Basbaum AI, Edwards RH (2009) Injury-induced mechanical hypersensitivity requires C-low threshold mechanoreceptors. Nature 462:651655. https://doi.org/10.1038/nature08505

153. Shin SM, Moehring F, Itson-Zoske B, Fan F, Stucky CL, Hogan $\mathrm{QH}, \mathrm{Yu} \mathrm{H}$ (2021) Piezo2 mechanosensitive ion channel is located 
to sensory neurons and nonneuronal cells in rat peripheral sensory pathway: implications in pain. Pain 162:2750-2768. https:// doi.org/10.1097/j.pain.0000000000002356

154. Sinica V, Zimova L, Barvikova K, Macikova L, Barvik I, Vlachova V (2019) Human and mouse TRPA1 are heat and cold sensors differentially tuned by voltage. Cells 9 https://doi.org/10. 3390/cells9010057

155. Sondermann JR, Barry AM, Jahn O, Michel N, Abdelaziz R, Kügler S, Gomez-Varela D, Schmidt M (2019) Vtilb promotes TRPV1 sensitization during inflammatory pain. Pain 160:508527. https://doi.org/10.1097/j.pain.0000000000001418

156. Steen AE, Reeh PW, Geisslinger G, Steen KH (2000) Plasma levels after peroral and topical ibuprofen and effects upon low $\mathrm{pH}$-induced cutaneous and muscle pain. Eur J Pain Lond Engl 4:195-209. https://doi.org/10.1053/eujp.2000.0173

157. Stevens RM, Ervin J, Nezzer J, Nieves Y, Guedes K, Burges R, Hanson PD, Campbell JN (2019) Randomized, double-blind, placebo-controlled trial of intraarticular trans-capsaicin for pain associated with osteoarthritis of the knee. Arthritis Rheumatol Hoboken NJ 71:1524-1533. https://doi.org/10.1002/art.40894

158. Story GM, Peier AM, Reeve AJ, Eid SR, Mosbacher J, Hricik TR, Earley TJ, Hergarden AC, Andersson DA, Hwang SW, McIntyre P, Jegla T, Bevan S, Patapoutian A (2003) ANKTM1, a TRP-like channel expressed in nociceptive neurons, is activated by cold temperatures. Cell 112:819-829

159. Suchyna TM, Tape SE, Koeppe RE, Andersen OS, Sachs F, Gottlieb PA (2004) Bilayer-dependent inhibition of mechanosensitive channels by neuroactive peptide enantiomers. Nature 430:235-240. https://doi.org/10.1038/nature02743

160. Sugimoto A, Miyazaki A, Kawarabayashi K, Shono M, Akazawa Y, Hasegawa T, Ueda-Yamaguchi K, Kitamura T, Yoshizaki K, Fukumoto S, Iwamoto T (2017) Piezo type mechanosensitive ion channel component 1 functions as a regulator of the cell fate determination of mesenchymal stem cells. Sci Rep 7:17696. https://doi.org/10.1038/s41598-017-18089-0

161. Syeda R, Qiu Z, Dubin AE, Murthy SE, Florendo MN, Mason DE, Mathur J, Cahalan SM, Peters EC, Montal M, Patapoutian A (2016) LRRC8 proteins form volume-regulated anion channels that sense ionic strength. Cell 164:499-511. https://doi. org/10.1016/j.cell.2015.12.031

162. Syeda R, Xu J, Dubin AE, Coste B, Mathur J, Huynh T, Matzen J, Lao J, Tully DC, Engels IH, Petrassi HM, Schumacher AM, Montal M, Bandell M, Patapoutian A (2015) Chemical activation of the mechanotransduction channel Piezo1. eLife 4 https://doi.org/10.7554/eLife.07369

163. Szczot M, Liljencrantz J, Ghitani N, Barik A, Lam R, Thompson JH, Bharucha-Goebel D, Saade D, Necaise A, Donkervoort S, Foley AR, Gordon T, Case L, Bushnell MC, Bönnemann CG, Chesler AT (2018) PIEZO2 mediates injury-induced tactile pain in mice and humans. Sci Transl Med 10:eaat9892 https://doi.org/10.1126/scitranslmed.aat9892

164. Szolcsányi J (2005) Hot peppers, pain and analgesics. In: Malmberg AB, Bley KR (eds) Turning up the heat on pain: TRPV1 receptors in pain and inflammation. Birkhäuser, Basel, pp 3-22. https://doi.org/10.1007/3-7643-7379-2_1

165. Szolcsányi J, Jancśo-Gábor A, Joo F (1975) Functional and fine structural characteristics of the sensory neuron blocking effect of capsaicin. Naunyn Schmiedebergs Arch Pharmacol 287:157169. https://doi.org/10.1007/BF00510447

166. Taberner FJ, Prato V, Schaefer I, Schrenk-Siemens K, Heppenstall PA, Lechner SG (2019) Structure-guided examination of the mechanogating mechanism of PIEZO2. Proc Natl Acad Sci U S A 116:14260-14269. https://doi.org/10.1073/pnas.1905985116

167. Takayama Y, Tominaga M (2018) Involvement of TRPV1-ANO1 interactions in pain-enhancing mechanisms. Adv Exp Med Biol 1099:29-36. https://doi.org/10.1007/978-981-13-1756-9_3
168. Thapa D, Valente J de S, Barrett B, Smith MJ, Argunhan F, Lee SY, Nikitochkina S, Kodji X, Brain SD (2021) Dysfunctional TRPM8 signalling in the vascular response to environmental cold in ageing. eLife 10:e70153 https://doi.org/10.7554/eLife.70153

169. Tominaga M, Caterina MJ, Malmberg AB, Rosen TA, Gilbert H, Skinner K, Raumann BE, Basbaum AI, Julius D (1998) The cloned capsaicin receptor integrates multiple pain-producing stimuli. Neuron 21:531-543. https://doi.org/10.1016/s08966273(00)80564-4

170. Touska F, Turnquist B, Vlachova V, Reeh PW, Leffler A, Zimmermann K (2018) Heat-resistant action potentials require TTXresistant sodium channels NaV1.8 and NaV1.9. J Gen Physiol 150:1125-1144. https://doi.org/10.1085/jgp.201711786

171. Tsagareli MG, Nozadze I (2020) An overview on transient receptor potential channels superfamily. Behav Pharmacol 31:413434. https://doi.org/10.1097/FBP.0000000000000524

172. Urien L, Gaillard S, Lo Re L, Malapert P, Bohic M, Reynders A, Moqrich A (2017) Genetic ablation of GINIP-expressing primary sensory neurons strongly impairs Formalin-evoked pain. Sci Rep 7:43493. https://doi.org/10.1038/srep43493

173. Vandewauw I, De Clercq K, Mulier M, Held K, Pinto S, Van Ranst N, Segal A, Voet T, Vennekens R, Zimmermann K, Vriens J, Voets T (2018) A TRP channel trio mediates acute noxious heat sensing. Nature 555:662-666. https://doi.org/10.1038/natur e26137

174. Wang L, You X, Lotinun S, Zhang L, Wu N, Zou W (2020) Mechanical sensing protein PIEZO1 regulates bone homeostasis via osteoblast-osteoclast crosstalk. Nat Commun 11:282. https:// doi.org/10.1038/s41467-019-14146-6

175. Wang L, Zhou H, Zhang M, Liu W, Deng T, Zhao Q, Li Y, Lei J, Li X, Xiao B (2019) Structure and mechanogating of the mammalian tactile channel PIEZO2. Nature 573:225-229. https://doi. org/10.1038/s41586-019-1505-8

176. Wang Y, Chi S, Guo H, Li G, Wang L, Zhao Q, Rao Y, Zu L, He W, Xiao B (2018) A lever-like transduction pathway for longdistance chemical- and mechano-gating of the mechanosensitive Piezo1 channel. Nat Commun 9:1300. https://doi.org/10.1038/ s41467-018-03570-9

177. Weller K, Reeh PW, Sauer SK (2011) TRPV1, TRPA1, and CB1 in the isolated vagus nerve-axonal chemosensitivity and control of neuropeptide release. Neuropeptides 45:391-400. https://doi. org/10.1016/j.npep.2011.07.011

178. Wes PD, Chevesich J, Jeromin A, Rosenberg C, Stetten G, Montell C (1995) TRPC1, a human homolog of a Drosophila storeoperated channel. Proc Natl Acad Sci U S A 92:9652-9656. https://doi.org/10.1073/pnas.92.21.9652

179. White JPM, Cibelli M, Urban L, Nilius B, McGeown JG, Nagy I (2016) TRPV4: molecular conductor of a diverse orchestra. Physiol Rev 96:911-973. https://doi.org/10.1152/physrev.00016. 2015

180. Wick EC, Hoge SG, Grahn SW, Kim E, Divino LA, Grady EF, Bunnett NW, Kirkwood KS (2006) Transient receptor potential vanilloid 1, calcitonin gene-related peptide, and substance $\mathrm{P}$ mediate nociception in acute pancreatitis. Am J Physiol Gastrointest Liver Physiol 290:G959-969. https://doi.org/10.1152/ajpgi. 00154.2005

181. Woo S-H, Ranade S, Weyer AD, Dubin AE, Baba Y, Qiu Z, Petrus M, Miyamoto T, Reddy K, Lumpkin EA, Stucky CL, Patapoutian A (2014) Piezo2 is required for Merkel-cell mechanotransduction. Nature 509:622-626. https://doi.org/10.1038/ nature 13251

182. Wood JN, Winter J, James IF, Rang HP, Yeats J, Bevan S (1988) Capsaicin-induced ion fluxes in dorsal root ganglion cells in culture. J Neurosci Off J Soc Neurosci 8:3208-3220

183. Wooten M, Weng H-J, Hartke TV, Borzan J, Klein AH, Turnquist B, Dong X, Meyer RA, Ringkamp M (2014) Three functionally 
distinct classes of C-fibre nociceptors in primates. Nat Commun 5:4122. https://doi.org/10.1038/ncomms5122

184. Yin Y, Wu M, Zubcevic L, Borschel WF, Lander GC, Lee S-Y (2018) Structure of the cold- and menthol-sensing ion channel TRPM8. Science 359:237-241. https://doi.org/10.1126/science. aan 4325

185. Zhang C, Medzihradszky KF, Sánchez EE, Basbaum AI, Julius D (2017) Lys49 myotoxin from the Brazilian lancehead pit viper elicits pain through regulated ATP release. Proc Natl Acad Sci U S A 114:E2524-E2532. https://doi.org/10.1073/pnas.16154 84114

186. Zhang K, Julius D, Cheng Y (2021) Structural snapshots of TRPV1 reveal mechanism of polymodal functionality. Cell 184:5138-5150.e12. https://doi.org/10.1016/j.cell.2021.08.012

187. Zhao J, Lin King JV, Paulsen CE, Cheng Y, Julius D (2020) Irritant-evoked activation and calcium modulation of the TRPA1 receptor. Nature 585:141-145. https://doi.org/10.1038/ s41586-020-2480-9
188. Zhu X, Tian C, Zhou Y, Shi J, Yuan G, Zhang L, Jiang Y, Xue W, Du Y, Hu Y (2021) Transient receptor potential channels: a global bibliometric analysis from 2012 to 2021 . Channels Austin Tex 15:624-634. https://doi.org/10.1080/19336950.2021.19831 00

189. Zimmermann K, Leffler A, Babes A, Cendan CM, Carr RW, Kobayashi J, Nau C, Wood JN, Reeh PW (2007) Sensory neuron sodium channel Nav1.8 is essential for pain at low temperatures. Nature 447:855-858. https://doi.org/10.1038/nature05880

Publisher's Note Springer Nature remains neutral with regard to jurisdictional claims in published maps and institutional affiliations. 